\title{
The Significance of Staff Assistance in Accessibility of Public Buildings
}

\author{
Syazwani Abdul Kadir, Mariam Jamaludin \\ Centre for Environment-Behaviour Studies, \\ Faculty of Architecture, Planning and Surveying, \\ Universiti Teknologi MARA, Shah Alam, Malaysia \\ syazwani@uwalumni.com
}

\begin{abstract}
This study intends to discuss the issue of public attitude towards PWD and the significance of staff assistance in public buildings. Semi-structured interviews were conducted with visually-impaired person, hearing-impaired person, wheelchair user and crutches user to find out their concerns on the accessibility of public buildings they assessed prior to the interview session. Findings show that other than the physical facilities, another important aspect of accessibility in a public building is staff assistance or hospitality towards visitors with disability. Public buildings should be able to cater the needs of all visitors, through physical and hospitality aspects of the building.

Keywords: Staff assistance; accessibility; persons with disabilities (PWD); public buildings

eISSN 2398-4279 @ 2018. The Authors. Published for AMER ABRA cE-Bs by e-International Publishing House, Ltd., UK. This is an open-access article under the CC BY-NC-ND license (http://creativecommons.org/licenses/bync-nd/4.0/). Peer-review under responsibility of AMER (Association of Malaysian Environment-Behaviour Researchers), ABRA (Association of Behavioural Researchers on Asians) and CE-Bs (Centre for EnvironmentBehaviour Studies), Faculty of Architecture, Planning \& Surveying, Universiti Teknologi MARA, Malaysia.

DOI: https://doi.org/10.21834/ajqol.v3i9.88
\end{abstract}




\subsection{Introduction}

Physical features of built environment have been the common focus in many accessibility studies; however, staff assistance and hospitality towards building visitors are also the significant criteria of an inclusive environment especially in public buildings. Staff assistance for visitors with disabilities particularly, is associated with the issue of social discrimination against disabled people and low public awareness on persons with disabilities (PWD) rights and capabilities.

Therefore, this study intends to address the issues of public attitude towards PWD and to emphasize on the significance of hospitality and staff assistance in public buildings. Objective of this study is to outline the importance of staff assistance in public buildings through PWD views from semi-structured interview data collection. This study hopes to lessen public ignorance of PWD rights to be treated equally as other people and raise awareness on hospitable environment in Malaysia.

\subsection{Literature Review}

\subsection{Significant Influence of Society on PWD Quality of Life}

Meyers et al. (2002) refer disability as the result of complex interactions between individuals and various elements of the surrounding environment; society, culture, politic, climate, topography, technology and architecture. Thus, it is acknowledged that society plays an important role in influencing the PWD quality of life. Encouraging attitude towards PWD may boost their self-esteem and foster their involvement in the community, while negative attitude and prejudice may demean them from participating in the social and economic mainstream (Abdul Kadir, Jamaludin and Abdul Rahim, 2013).

Social model of disability views PWD exclusions from the mainstreams as the result of public stereotype and ignorance of their capabilities and rights (Gartner and Joe, 1987; Antonak and Livneh, 2000; Meyers et al., 2002; Wiman and Sandhu, 2004). According to Shakespeare (2006), the social model of disability also argues that PWD has been socially oppressed and discriminated by the society. This leads to the discussion on PWD social discrimination due to public ignorance of their rights and capabilities to contribute to the society.

\subsection{Public Ignorance of PWD Rights and Capabilities}

Among major social factors that cause PWD exclusions from the mainstreams are negative support from the society and low public awareness on PWD rights and capabilities (Antonak and Livneh, 2000; Meyers at al., 2002; Putnam et al, 2003; Wiman and Sandhu, 2004). Most of the able-bodied people do not put themselves in PWD sentiment and life situation. Moreover, majority of them are not closely related to a disabled person as a friend or family member. This lack of interaction or experience with PWD causes many people to have little knowledge, poor understanding and negative support towards the PWD rights to develop better quality of life. 
On top of that, the disabled people have always been seen as the "unavoidable cost" to the society (Metts, 2004). Rather than being viewed as an economic investment, the expenditures on disability, which is normally a part of the governmental financial planning, have always been seen as burdensome to the citizens who pay taxes every year. In addition, the negative support from society has witnessed many facilities for disabled people are often abused by other people. As an example, the PWD parking space in Malaysia is always occupied or 'stolen' by the able-bodied driver.

Malaysia has also established the first right-based legislation for people with disabilities, entitled Malaysian Persons with Disabilities Act (2008), Chapter 1 which underlines PWD rights to easily access public facilities, amenities, services and buildings; public transport facilities; education; employment; information, communication and technology; cultural life; and recreation, leisure and sport. Abdul Rahim (2008) lists three main objectives of the proposal of Persons with Disabilities Act in 2002 as:

- To ensure that persons with disabilities in Malaysia have the same rights to equality before the law as the rest of the community in the country.

- To eliminate, as far as possible, discrimination against persons on the ground of disability in various areas of life.

- To promote recognition and acceptance within the community of the principle that persons with disabilities be afforded equal opportunities and full participation to enable them to live as a rightful citizen of the country.

This means that PWD have the right to be treated equally like other citizens, and public are urged to eliminate the social oppressions towards PWD in every aspects of life including hospitality in public accommodations and physical accessibility in the built environment.

\subsection{Physical Accessibility and Hospitality in Public Buildings}

Poor support from building developers and designers has also caused PWD exclusions from the mainstreams due to physical barriers in architecture. Many acts and standards have been enacted by the Malaysia government; however, many professionals prefer to neglect their moral responsibility to provide accessible public facilities as to gain faster profit. They lack awareness that a convivial place may attract more visitors and generate more economic activities within the environment (Shaftoe, 2008).

Other than the designers and building developers, managers and staff of public buildings also play vital roles in providing an accessible and hospitable environment to the visitors, especially the visitors with disabilities. A survey found that, in the general context of service provision, about $40 \%$ of the PWD respondents emphasize more on positive attitude from the staff than other factors such as money value paid for the service (DRC, 2003). However, there still poor hospitality by the staff and building managers towards visitors with disabilities, which is rooted from their lack of skills on how best to interact with PWD, and their stereotype towards the disabled people as well (Goodall et al., 2004).

Some scholars establish that hospitality or also known as staff assistance is an important element of accessibility. For instance, Abdul Shukor and Othman (2010) and Abdul Rahim and Abd Samad (2010) address the demand of "disabled attendees" in public 
buildings. Kose (2006) also recognizes "personal intervention" such as sign language, helpful and friendly staff, and staff who are good at interacting with PWD as more effective and logical in helping PWD to access a building. Holmes-Siedle (1996), in his book of barrier-free design in architecture, emphasizes on the significance of front-liner staff in providing accessibility for visitors. He claims that front-line staff "can either welcome disabled people into the building or exclude them before they arrive".

\subsection{Methodology}

\subsection{Semi-Structured Interview}

This study conducted semi-structured interviews with four PWD participants to find out what are the most concerned aspects of accessibility in public buildings they assessed prior to the interview session. PWD vulnerability to the social oppressions is the rationale for this study to focus on PWD feedbacks on issues related to disability and accessibility. Moreover, unlike structured questionnaires, the semi-structured interview allows participants to have more control on the outcome rather than being controlled by the researcher. This may provide indepth, honest and vital views related to the research problems from the users' perspectives.

The semi-structured interview is a part of access audit data collection conducted for the assessed buildings. Access audit is the method to examine an existing building against predetermined criteria, which are designed to measure the 'usability' of the building for disabled people (Holmes-Siedle, 1996). A comprehensive access audit examines not only for the wheelchair-bound person, but also other disabilities like sensory disabled and mental disabled people (Holmes-Siedle, 1996).

There are some precedent studies which have conducted access audit and interviews to get PWD feedbacks on the building's accessibility (Thapar et al., 2004; Mohd Yaacob and Hashim, 2007; Rashid, Hussain and Yusuff, 2008; Jamaludin, Mohd Ali and Mohamad, 2010). However, most findings of these studies focus more on the physical barriers in architecture; thus, this study intends to complement the precedent researches with an emphasis on staff assistance in the built environment.

\subsection{Participants}

The four PWD participants (visually impaired person, hearing impaired person, wheelchair user, and crutches user) were recruited from various PWD associations which are located close to Putrajaya; the Malaysian Association for the Blind, the Negeri Sembilan Deaf Society, and the Society of the Orthopedically Handicapped Malaysia. All four participants remained constant throughout the interview data collection for all assessed buildings.

\subsection{Research Location and the Assessed Buildings}

Putrajaya is chosen as the location of study due to its identity as the centre for government administration and as a new tourist attraction in Malaysia. It locates many public buildings that serve various kinds of people in a daily basis. A survey study on residents' perception of Putrajaya identity found that most respondents indicated buildings as the unique symbols 
and distinctive identity to Putrajaya (Ismail, Shamsuddin and Sulaiman, 2008). This shows that architecture is the strongest element that attracts the city's residents and tourists; thus, it is vital to ensure that public buildings in Putrajaya are accessible and user-friendly.

The five assessed public buildings were chosen purposely to represent different location and function for the use of the city residents and public visitors, as summarized in Table 1.

Table 1: The Five Assessed Public Buildings

\begin{tabular}{|l|l|l|}
\hline Name of Building & Function & Location \\
\hline $\begin{array}{l}\text { Department of } \\
\text { Immigration }\end{array}$ & $\begin{array}{l}\text { Federal government administrative office for Department of } \\
\text { Immigration. }\end{array}$ & Precinct 2 \\
\hline Natural History Museum & $\begin{array}{l}\text { Informal science education centre, gallery/ museum, and centre for } \\
\text { research on Malaysian heritage flora and fauna. }\end{array}$ & Precinct 15 \\
\hline $\begin{array}{l}\text { Perdana Leadership } \\
\text { Foundation }\end{array}$ & $\begin{array}{l}\text { Educational foundation and library for learning about Malaysian } \\
\text { leadership and nation-building. }\end{array}$ & Precinct 8 \\
\hline PICC & $\begin{array}{l}\text { Event and conference venue; MICE (Meetings, Incentives, } \\
\text { Conventions and Exhibitions) facility. }\end{array}$ & Precinct 5 \\
\hline Tuanku Mizan Mosque & $\begin{array}{l}\text { Worshipping place and religious centre for Muslims, and } \\
\text { international Islamic educational centre. }\end{array}$ & Precinct 3 \\
\hline
\end{tabular}

\subsection{Limitation}

This study data may be affected by emotional and personal responses from the PWD participants due to social discriminations they have experienced during their life as disabled people. However, the results show that they have provided practical recommendations to improve the accessibility of the assessed buildings based on their views as PWD. They also hold a high position in their association (which implies professionalism) and have often involved in access audit study.

\subsection{Findings and Discussion}

Findings of the semi-structured interview can be summarized as in Table 2. Their feedbacks provide practical suggestions on how to improve the accessibility of the assessed buildings as well as all public buildings in Malaysia generally.

From the feedbacks, it is shown that other than physical barriers of the assessed buildings, staff assistance is also a significant aspect of accessibility in the eyes of PWD. The visually-impaired participant, apart from her concerns on guiding blocks provision, she proposes a briefing on the emergency means of escape for PWD visitors prior to events held in any public buildings. In addition, she also emphasizes on the personal intervention or staff assistance if the building cannot provide thorough physical accessibility. Similarly, the hearing-impaired participant focuses mainly on the quality of staff assistance and hospitality in all assessed buildings. She urges that staff assistance and attitude towards visitors with disabilities are really significant, thus learning communication skills to interact with PWD such as sign language is necessary for all front-liner staff.

While the wheelchair-bound participant focuses more on the physical attributes of the assessed buildings, the crutches user proposes two aspects of hospitality in a public building 
which have always been overlooked by other people. He asserts that emergency alarm in PWD restroom is really essential especially in the case of an accident or emergency situation. Furthermore, public seating located close to the reception counter should be provided for visitors especially for those with physical limitations

Table 2: Participants Feedbacks of the Semi-Structured Interview

\begin{tabular}{|c|c|}
\hline PWD Participants & Feedbacks of the semi-structured interview \\
\hline $\begin{array}{l}\text { Visually-impaired } \\
\text { participant }\end{array}$ & $\begin{array}{l}\text { Should have a briefing on the emergency means of escape at the beginning of event } \\
\text { participated by visually impaired people or any PWD. } \\
\text { Also, if the building is not accessible, assistance from staff is needed. } \\
\text { Staff should be taught how to assist PWD during daily routine and emergency situation. } \\
\text { Provide appropriate guiding blocks which direct to main areas of public buildings such as } \\
\text { the main entrance, reception counter, and elevators. }\end{array}$ \\
\hline $\begin{array}{l}\text { Hearing-impaired } \\
\text { participant }\end{array}$ & $\begin{array}{l}\text { Staffs need to learn some basis of sign language through a short course or class. } \\
\text { Staff communication, attitude and treatment towards PWD are very important to PWD. }\end{array}$ \\
\hline $\begin{array}{l}\text { Wheelchair- } \\
\text { bound participant }\end{array}$ & $\begin{array}{l}\text { Most facilities have considered the wheelchair user but there are still incorrect } \\
\text { installations or design. } \\
\text { Therefore, building needs to do some modification based on the current standards. }\end{array}$ \\
\hline Crutches User & $\begin{array}{l}\text { Provide emergency alarm in PWD restroom in case of emergency or the user needs } \\
\text { help. } \\
\text { Public seating close to the reception counter may be helpful to visitors with physical } \\
\text { limitation. } \\
\text { May also provide a special area for PWD at the ablution area. }\end{array}$ \\
\hline
\end{tabular}

These findings show that other than the physical facilities, one of the important aspects of accessibility in a public building is the staff assistance and hospitality towards visitors with disabilities. Excellent staff assistance is significantly crucial when providing full accessibility in the built environment is impossible; for example, when it is difficult to alter a heritage building in order to conserve the building's heritage value. As much the PWD want to be independent, when the space is unavoidably inaccessible, they would really appreciate people assistance to help them escape from physical barriers they encounter in the building.

\subsection{Conclusion}

In a conclusion, hospitality and staff assistance in public buildings are significantly important to the needs and accessibility of visitors with disabilities. More studies that focus on staff assistance and attitude towards disabled visitors in public buildings need to be conducted to ensure an inclusive environment that can cater the needs of all visitors including PWD, through physical as well as hospitality aspects of the building. The staff attitude is significant in ensuring the accessibility of a building because a negative or unwelcoming attitude from the staff may keep the visitors away from that building.

The staff assistance should be emphasized mostly to the front-liner staff as they are the first person whom visitors approach upon arriving at the building. Staffs need to be taught on how to interact with PWD and they also need to be ready and willing to assist visitors who need help anytime during their service, especially during an emergency situation (Goodall et 
al., 2004; Abdul Rahim and Abd Samad, 2010). In addition to that, this study proposes a list of guidelines for front-liner staff in regards to good hospitality practice, as follows:

- Be assistive and welcoming through phone call which were made prior visitor coming to the building, so that they can plan ahead and require special facilities such as wheelchair.

- $\quad$ Be aware of the attendance of visitors especially PWD. They feel stigmatized when being ignored by the receptionist, especially when they realize that the receptionist tries to avoid being burdened to assist them.

- Be friendly and welcoming all the times. Smile always and be a good listener to understand visitors' needs.

- Know how to communicate using various medium depends on different people or situation. Useful medium includes map, brochure, pen and paper, business card and sign language (significantly important).

- Know how to assist thoroughly. Responsibility of receptionist is not only to greet visitors, but also to assist them to be at their event or destination. Provide assistant (other staff) to show the place if the visitors really need help (this is an example of people assistance).

- In an emergency situation, staff needs to know how to assist visitors to the gathering point, especially the PWD, and know how to control the emergency situation or calm the panic visitors.

Additional recommendation by building managers in regards to inclusive hospitality include providing speech translator for talk events and to train an emergency or fire rescue team who are also skilled in assisting PWD during a fire emergency situation (Abdul Kadir, Jamaludin and Abdul Rahim, 2013).

On top of staff assistance and hospitality in public buildings, society also needs to be educated about the importance of barrier-free environment and PWD rights and capabilities. One of the effective ways to encourage positive support among the community is by getting everybody involved in PWD experience through campaigns and interactive activities with disabled people.

Future researches may be conducted concerning on the staff training or attitude audit (Holmes-Siedle, 1996) among building managers and staffs including those who are impaired. Another future research topic may focus on the accessible tourism in Malaysia which also highlights the hospitality as a significant aspect in an inclusive environment for all tourists especially the tourists with disabilities.

\section{Acknowledgement}

Deepest appreciation to Research Management Institute (RMI) UiTM for funding the research project, and also to the interview participants from the Malaysian Association for the Blind, Negeri Sembilan Deaf Society and the Orthopedically Handicapped Malaysia for their kind cooperation and helpful feedbacks. 


\section{References}

Abd Shukor, S. and Othman, N.A. (2010). Attitude of Event Organisers towards Disabled Attendees for the Development of Barrier-Free Tourism Events. The $5^{\text {th }}$ World Conference for Graduate Research in Tourism, Hospitality and Leisure, 25 - 30 May 2010, Cappadocia, Turkey, 634-649.

Abdul Rahim, A. (2008) What is Access Audit and Access Audit for Existing Buildings in Meeting Universal Designs, Workshop on Access Audit for "Kajian Audit Akses Untuk Ruang Awam bagi Orang Kurang Upaya di Malaysia" for Ministry of Women, family and Community Development, $7^{\text {th }}$ to $8^{\text {th }}$ June 2008.

Abdul Rahim, A. and Abd. Samad, N.A. (2010). Accessible Built Environment for the Elderly and Disabled in Malaysia: Hotels as Case Studies. Journal of Construction in Developing Countries, 15(2), 1-21.

Antonak, R.F. and Livneh, H. (2000). Measurement of Attitudes Towards Person with Disabilities. Disability and Rehabilitation, 22(5), 211-224.

Disability Rights Commission (DRC) (2003). The Disability Discrimination Act 1995: What Do Guest Accommodation Owners Need to Know? DRC, Manchester.

Gartner, A. \& Joe, T. (Eds.), (1987). Images of the Disabled, Disabling Images. Praeger, New York.

Goodall, B., Pottinger, G., Dixon, T., \& Russell, H. (2004). Heritage property, tourism and the UK Disability Discrimination Act. Property Management, 22(5), 345 - 357.

Holmes-Siedle, J. (1996). Barrier-free Design: A manual for building designers and managers. ButterworthHeinemann Ltd: Oxford.

Ismail, I.S., Shamsuddin, S. and Sulaiman, A.B. (2008). An Evaluation of Residents Perception of Identity in Putrajaya New Town, Jurnal Alam Bina, 13(4).

Jamaludin, M., Mohd Ali, H. and Mohammad, E. (2010). Accessibility for Person with Disability in Tourism. The $5^{\text {th }}$ World Conference for Graduate Research in Tourism, Hospitality and Leisure, 25 - 30 May 2010, Cappadocia, Turkey, 383-394.

Kose, S. (2006). Universal Design for the Aging. In International Encyclopedia of Ergonomics and Human Factors (edited by W. Karwowski), CRC Press, 227-230.

Mohd Yaacob, N. and Hashim, N.R. (2007). Inclusive Heritage Toursim: A study on the access needs of dsiabled and elderly tourists in Malaysia. The $3^{\text {rd }}$ Tourism Outlook Conference and Global Event Congress II, Kuala Lumpur, July 16-18, 2007. 227-239.

Metts, R. (2004). Disability and development. Background paper prepared for the Disability and Development Research Agenda Meeting, World Bank Headquarters, Washington D.C. 16 November 2004.

Meyers, A.R., Anderson, J.J., Miller, D.R., Shipp, K. \& Hoenig, H. (2002). Barriers, Facilitators, and Access for Wheelchair Users: Substantive and methodologic lessons from a pilot study of environmental effects. Social Science \& Medicine, 55, 1435-1446.

Persons with Disabilities Act (2008). Percetakan Nasional Malaysia Berhad.

Putnam, M., Greenen, S., Powers, L., Saxton, M., Finney, S. and Dautel, P. (2003). Health and Wellness: People with disabilities discuss barriers and facilitators to well being. Journal of Rehabilitation, 69, 37-45. 
Rashid, S.N.S.A., Hussain, M.R.H. \& Yusuff, R.M. (2008). Designing Homes for the Elderly Based on the Anthropometry of Older Malaysians. Asian Journal of Gerontology Geriatrics, 3, 75-83.

Shaftoe, H. (2008). Convivial Urban Spaces, Earthscan: United Kingdom and United States of America.

Shakespeare, T. (2006). The Social Model of Disability. The Disability Studies Reader (2nd Ed). Routledge: New York.

Thapar, N., Warner, G., Drainoni, M.L., William, S.R., Ditchfield, H., Wierbicky, J. and Nesathurai, S. (2004). A Pilot Study of Functional Access to Public Buildings and Facilities for Persons with Impairments. Disability and Rehabilitation, 26(5), 280-289.

Wiman, R. \& Sandhu, J. (2004). Integrating Appropriate Measures for People with disabilities in the Infrastructure Sector. A study in collaboration with Deutsche Gesellschaft fur Technische Zusammenarbeit (GTZ), the National Research and Development Centre for Welfare and Health in Finland (STAKES), and Inclusive Design Associates Limited (INDRA). 